\title{
Marcelina Leśniczak
}

Marcelina Leśniczak - doktor nauk humanistycznych, japonistka, asystent w Pracowni Języka i Kultury Japońskiej Uniwersytetu Mikołaja Kopernika. Absolwentka Uniwersytetu im. Adama Mickiewicza, stypendystka japońskiego Ministerstwa Edukacji (Monbushō) i The Japan Foundation. Jej zainteresowania badawcze obejmują: współczesną literaturę japońską, twórczość Tanizakiego Jun'ichirō, literaturę okresu Edo, teatr japoński (ningyō jōruri/bunraku, kabuki). 


\section{Dziecięce i młodzieńcze fascynacje Tanizakiego Jun'ichirō światem teatru kabuki}

DOI: http://dx.doi.org/10.12775/LC.2014.024

\section{Eseje jako źródła biograficzne}

moim przypadku większość tego, co teraz sobą reprezentuję, o dziwo, zostało we mnie zaszczepione w okresie wczesnego dzieciństwa. Natomiast to, z czym zetknąłem się w okresie dojrzewania, nie miało zbyt dużego wpływu na mój rozwój” ${ }^{1}$.

Cytat ten pochodzi z krótkiego eseju Tanizakiego Jun'ichirō Watashi no „Yōshō jidai” ni tsuite (O moim „Czasie dzieciństwa”, czerwiec 1955). Pisarz przez całe życie z upodobaniem wypowiadał się w formie eseistycznej, a zwłaszcza w latach 50. XX wieku, gdy zaczął podupadać na zdrowiu i dotkliwie odczuwał postępujący proces starzenia się i niedołężnienia.

Wszystkie szkice literackie Tanizakiego mają charakter autobiograficzny i są pełne rozważań o codziennym życiu, rodzinie, współczesnej mu literaturze, teatrze, rynku wydawniczym, a także relacji z przyjęć organizowanych w środowisku pisarzy. Cztery tomy tych esejów stanowią część trzydziestotomowej edycji Tanizaki Jun'ichirō zenshū (Dzieła zebrane Tanizakiego Jun'ichirō) i dostarczają bezcennej wiedzy o pisarzu, który - jako człowiek skryty i stroniący od ludzi - poza tymi spisanymi przez siebie zwierzeniami niechętnie

1 J. Tanizaki, Watashino "Yōshōjidai" ni tsuite, [w:] Tanizaki Jun'ichirō zenshū (=TJZ), t. 22, s. 400-402. O ile nie podano inaczej, wszystkie cytowane tłumaczenia wykonała autorka.

2 Tanizaki Jun'ichirō (1886-1965) - jeden z najwybitniejszych japońskich pisarzy XX wieku, przedstawiciel nurtu tanbiha (szkoła estetów, japoński neoromantyzm). Do ulubionych wątków tematycznych, które Tanizaki podejmował w większości swoich utworów należą między innymi: piękno kobiecego ciała, miłość masochistycznego mężczyzny gotowego cierpieć w imię takiego piękna, trójkąty miłosne, pełne namiętności niemoralne związki, miłość kazirodcza do matki, a w ostatnim okresie twórczości również starość i obumieranie sił witalnych. Polskim czytelnikom Tanizaki znany jest dzięki przekładom Mikołaja Melanowicza (np. Dziennik szalonego starca. Niektórzy wola pokrzywy, Warszawa 1972). 
zdradzał tajemnice swojej prywatności i procesu pisania. Tanizaki dał temu wyraz w eseju Yomu koto sura kirai (Nawet czytać nie lubię, 1922) ${ }^{3}$ przyznając, że nie ma w zwyczaju wypowiadać się na temat własnych utworów czy dzieł swoich kolegów-pisarzy. Eseje te są więc jedynym źródłem bezcennych, najbardziej wiarygodnych (bo napisanych przez samego autora) informacji biograficznych.

Zacytowany fragment $O$ moim "Czasie dzieciństwa” jest uzupełnieniem powstałego w marcu tego samego roku długiego eseju Yōshō jidai (Czas dzieciństwa, 1955) ${ }^{4}$, który na tle licznych esejów pisarza stanowi, wraz z Seishun monogatari (Opowieść o młodości, $1932)^{5}$ oraz z esejem Setsugoan yawa (Nocne rozmowy w „schronieniu po śniegu”6, 1963) 7 , najważniejsze źródło wiedzy o dzieciństwie i wczesnej młodości pisarza.

W Czasie dzieciństwa Tanizaki opisuje Japonię przełomu XIX/XX wieku oraz mgliste wspomnienia okresu dziecięcego, natomiast w Opowieści o młodości przedstawia fakty z okresu swojej młodości po 1907 roku. Uwiecznione w esejach doświadczenia z okresu dzieciństwa w rzeczywistości miały - jak sam Tanizaki przyznaje w przytoczonym fragmencie Czasu dzieciństwa - decydujący wpływ na ukształtowanie jego charakteru, światopoglądu, wyrafinowanego gustu artystycznego, a także - jak się później okaże - twórczości.

Eseje Czas dzieciństwa, Opowieść o młodości oraz Nocne rozmowy w „schronieniu po śnie$g u$ ", a zwłaszcza jego ostatni rozdzial ${ }^{8} \mathrm{w}$ całości poświęcony dramatowi kabuki ${ }^{9}$ pt. Yoshitsune senbon-zakura (Yoshitsune, czyli tysiąc wiśni) ${ }^{10}$ wraz z innymi esejami zacytowanymi poniżej są szczególnie cenną skarbnicą wiedzy na temat zainteresowania pisarza tradycyjnym teatrem japońskim. Dostarczają wiedzy o tym, kto zaszczepił w pisarzu zamiłowanie do kabuki, jakich aktorów najbardziej podziwial, z kim się przyjaźnił, na jakie aspekty przedsta-

3 J. Tanizaki, Yomu koto sura kirai, [w:] TJZ, t. 23, s. 64.

${ }^{4}$ Idem, Yōshō jidai, [w:] TJZ, t. 17, s. 41-253.

${ }^{5}$ Idem, Seishun monogatari, [w:] TJZ, t. 13, s. 343-439.

${ }^{6}$ Tanizaki Jun'ichirō, z powodu nadciśnienia i innych problemów zdrowotnych, musiał się przenieść z Kioto do Atami w lutym 1950 roku. Nowe mieszkanie nazwał "Setsugoan”, czyli „schronienie po śniegu”. Nazwa domu nawiązywała do tytułu powieści Sasameyuki (Śnieżynki), ponieważ słowa setsu i yuki oznaczają śnieg. Pisarz zamieszkał w tym domu po opublikowaniu tej powieści. Zob. M. Melanowicz, Tanizaki. Japoński most snów, Warszawa 1994, s. 31.

7 Idem, Setsugoan yawa, [w:] TJZ, t. 19, s. 375-459.

8 Idem, „Yoshitsune senbon-zakura no omoide”, w: Setsugoan yawa, [w:] TJZ, t. 19, s. 448-460.

${ }^{9}$ Kabuki - jeden z czterech gatunków japońskiego teatru klasycznego; powstał jako rozrywka mieszczan. Nazwę zapisuje się trzema ideogramami, które oznaczają pieśń $(k a)$, taniec $(b u)$ oraz grę $(k i)$. Szerzej na ten temat zob.: M. Melanowicz, Literatura japońska, t. 1: Od VI do połowy XIX wieku, Warszawa 1994, s. 411-481; E. Żeromska, J. Rodowicz, hasło „kabuki”, [w:] J. Tubielewicz, Kultura Japonii. Słownik, Warszawa 1996, s. 128-132; E. Żeromska, Japoński teatr klasyczny. Korzenie i metamorfozy, t. 2: Kabuki, bunraku, Warszawa 2010, s. 19-227.

10 Yoshitsune senbon-zakura - siedmioaktowa sztuka historyczna (jidaimono) napisana w 1747 r. przez Takedę Izumo II (1691-1756), Miyoshiego Shōraku (1695-1771), Namikiego Sōsuke (inaczej: Namiki Senryū, 16951751). Obecna w repertuarze jōruri (bunraku) i kabuki (maruhon-mono). Premiera tego utworu odbyła się w 1747 r. w teatrze lalkowym Takemoto-za w Osace, a w 1748 r. została wystawiona na scenie teatru kabuki Nakamura-za w Edo (obecne Tokio). Tłem sztuki jest konflikt i walki dwu zwaśnionych rodów - Minamoto (Genji) i Taira (Heike). Głównym bohaterem jest Yoshitsune, który po konflikcie z bratem jest przez niego prześladowany i musi się ukrywać - to jest tematem pierwszego aktu. W drugim akcie ukazane jest rozstanie Yoshitsune z jego ukochaną Shizuką Gozen. Powierza jej drogocenny bęben, który podarował mu cesarz. Na odgłos tego bębna u boku Shizuki pojawia się Tadanobu, sługa Yoshitsune. Jest to w rzeczywistości lis przeistoczony w człowieka. W akcie czwartym przedstawiona jest Shizuka Gozen w Yoshino, podróżuje (michiyuki) z lisem-Tadanobu i wykonują razem taniec, przez który wyrażają radość ze spotkania z Yoshitsune, ukochanym Shizuki Gozen. W ostatnim akcie sztuki wyjaśniona zostaje historia lisa-Tadanobu. Pod koniec dramatu dochodzi do szczęśliwego spotkania Shizuki Gozen z ukochanym Yoshitsune, który dziękuje lisowi za wierne towarzyszenie jego umiłowanej Shizuce Gozen. Zob. A. S. Halford, G. M. Halford, The Kabuki handbook: a guide to understanding and appreciation, Tokyo 1990, s. 179-183. 
wienia zwracał zwykle szczególną uwagę, a ponadto o wpływie, jaki obejrzane sztuki kabuki wywarły na powstanie konkretnych utworów. Eseistyczna twórczość Tanizakiego dowodzi ponadto, że pisarz był nie tylko wielkim admiratorem, lecz także niezrównanym znawcą teatru w ogóle.

\section{Pierwsze wizyty małego Tanizakiego w teatrze kabuki}

W 1894 roku, w wyniku nietrafionych inwestycji ojca pisarza, sytuacja materialna rodziny Tanizakich zaczęła się dramatycznie pogarszać ${ }^{11}$. W tym trudnym okresie pomagał im finansowo brat matki, Shōshichi, oraz brat ojca, Kyūemon. To oni dbali o to, żeby małemu Jun'ichirō i jego rodzeństwu zapewnić rozrywkę i pozwalać czasami zapominać o biedzie oraz problemach dnia codziennego.

Zainteresowanie małego Tanizakiego teatrem dostrzegł Shōshichi - erudyta, koneser sztuki japońskiej oraz tradycyjnego teatru japońskiego. To on przyczyniał się do rozwoju tych zamiłowań, regularnie zabierając małego Jun'ichirō na spektakle kabuki wystawiane w profesjonalnych teatrach, jak na przykład w Kabuki-za ${ }^{12}$. Można powiedzieć, że starannie zadbał o wczesną edukację teatralną Tanizakiego, któremu imponował też znajomością tajników tradycyjnej narracji gidayu $\overline{ }^{13}$ i tym, że sam się jej uczył.

Dzięki tym pierwszym w swoim życiu wizytom w kabuki przyszły pisarz miał okazję poznawać ów teatr w okresie, kiedy był już zakończony proces wcielania reform przez powołane w 1886 roku Towarzystwo Reform Teatralnych (Engeki Kairyōkai). Reformy polegały między innymi na stworzeniu teatru „przyzwoitego”, dobrego dla dzieci i dorosłych, odzwierciedlającego w realistyczny sposób aktualną rzeczywistość, realizującego dawną zasadę moralistyczną kanzen chōaku (nagradzanie dobra, ganienie zła) ${ }^{14}$. Zmiany spowodowały, że opierano się na klasycznym repertuarze, ale wzbogaconym o większy realizm i zgodnym z programem reform.

Badacz twórczości Tanizakiego, Yamaguchi Masahiko (ur. 1958), akcentuje fakt, że najprawdopodobniej kabuki przedstawione małemu Tanizakiemu przez wuja było eksperymentalnym połączeniem klasycznego kabuki z katsurekimono. Prekursorem i wielkim propagatorem katsurekimono był aktor Ichikawa Danjūrō IX (1838-1903). Tanizaki ze względu na zbyt młody wiek nie mógł jednak rozpoznać eksperymentalnego charakteru

11 W 1894 r. zbankrutował prowadzony przez ojca Tanizakiego sklep z importowanymi z Zachodu artykułami oraz firma zajmująca się zapalaniem wieczornych latarni. Rodzina pozbawiona comiesięcznych przychodów przez pewien czas musiała utrzymywać się ze spadku pozostawionego przez zmarłego w 1888 r. dziadka (ojca matki Tanizakiego). Finansowo wspierał ich także brat matki - wuj Shōshichi, który prowadził dobrze prosperujący zakład poligraficzny.

12 Kabuki-za - teatr kabuki powstały w 1889 r. w Tokio w dzielnicy nazywanej wówczas Kyōbashi (obecnie przy ulicy Ginza).

${ }_{13}$ Gidayū - narracyjny styl muzyki wokalnej w przedstawieniach lalkowych jōruri oraz w kabuki, a także kantor wykonujący ten śpiew. Nazwa pochodzi od imienia artysty Takemoto Gidayū (1651-1714), który jako pierwszy wprowadził ten styl. Inne nazwy: tayū (używana w bunraku na określenie kantora), chobo. Kantor współdziała z zespołem muzyków grających na shamisenie - trzystrunowym, przypominającym banjo instrumencie.

14 E. Żeromska, Japoński teatr klasyczny, t. 2, s. 34. 
widowiska ${ }^{15}$. Yamaguchi wskazuje też na wszechstronną wiedzę pisarza o historii kabuki przejawiającą się tym, że w eseju Czas dzieciństwa Tanizaki często odwołuje się do prekursorskich opracowań ${ }^{16}$ wybitnych badaczy tego klasycznego teatru japońskiego, takich jak Tamura Nariyoshi (1851-192), Okamoto Kidō (1872-1939) i Ihara Toshio (1870-1941).

\section{Tanizaki a kabuki: aktorzy, repertuar, twórcze inspiracje}

W esejach Yōnen no kioku (Wspomnienia dziecka, 1947) ${ }^{17}$, Shiki (Cztery pory roku, 1962) ${ }^{18}$, Geidan (Rozmowy o sztuce, 1933) ${ }^{19}$, Jōzetsuroku (Kronika gadulstwa, 1927) ${ }^{20}$, Kyūyū Ichikawa Sadanji o itamu (Wspominając ze smutkiem starego przyjaciela Ichikawę Sadanjiego, 1940) ${ }^{21}$, Katami no shinajina ni matsuwaru omoide (Wspomnienia związane z pamiątkami po nieobecnych, 1956) ${ }^{22}$ Tanizaki wiele miejsca poświęca teatrowi kabuki, który w całym jego życiu, osobistym i zawodowym, zajmował bardzo ważne miejsce. W esejach ze znawstwem analizuje obejrzane przez siebie przedstawienia i pojedyncze kreacje aktorskie, wspomina bezpośrednie spotkania z artystami (Ichikawą Danjūrō IX, Onoe Kikugorō V, Ichikawą Sadanjim II), opowiada o swoich ulubionych sztukach i często powracających w nich motywach, opisuje własne inspiracje, których można się doszukać w różnych utworach.

\section{Fascynacje aktorskie}

\section{Ichikawa Danjūrō IX}

W eseju Wspomnienia dziecka Tanizaki relacjonuje, że najwcześniej obejrzaną przez niego sztuką kabuki była Kanjinchō (Lista subskrypcyjna, 1702) Namiki Goheia III (17891855), w której główną rolę grał Ichikawa Danjūrō IX. Spektakl ten widział w 1895 roku w tokijskim teatrze Shintomi-za. Tanizaki miał wtedy zaledwie dziewięć lat, ale kreacja Danjūrō IX zrobiła na nim wielkie wrażenie. Po latach uznał go za aktora wszech czasów ${ }^{23}$. Jego wielbicielami byli też matka i wuj pisarza, którzy często zabierali małego Tanizakiego do tokijskich teatrów Kabuki-za i Shintomi-za.

${ }^{15}$ M. Yamaguchi, Nihon no sakka hyakunin. Tanizaki Jun'ichirō. Hito to bungaku (Stu japońskich pisarzy. Tanizaki Jun'ichirō - człowiek i literatura), Tōkyō 2004, s. 55.

16 Ibidem, s. 56.

17 J. Tanizaki J., Yōnen no kioku, [w:] TJZ, t. 23, s. 198-228.

18 Idem, Shiki, [w:] TJZ, t. 19, s. 175-200.

19 Idem, Geidan, [w:] TJZ, t. 20, s. 411-454.

20 Idem, Jōzetsuroku, [w:] TJZ, t. 20, s. 69-166.

${ }^{21}$ Idem, Kyūyū Ichikawa Sadanji wo itamu, [w:] TJZ, t. 22, s. 339-345.

22 Idem, Katami no shinajina ni matsuwaru omoide, [w:] TJZ, t. 23, s. 447-448.

${ }^{23}$ Idem, Yōnen no kioku, [w:] TJZ, t. 23, s. 198. 
W eseju Cztery pory roku, w całości poświęconym Danjūrō IX autor opisuje, jak matka entuzjastycznie reagowała na pojawienie się tego aktora na scenie, wykrzykując: „Popatrz, popatrz! To sam Danjūrō!” ${ }^{24}$. Wujek pisarza natomiast skarżył się małemu Tanizakiemu, że podczas spektakli z udziałem innego popularnego aktora, Onoe Kikugorō V (1844-1903), przerwy między aktami są zbyt długie - zapewne, jak można się domyślić, z powodu przeciągających się owacji. Dlatego wuj wolał wchodzić na widownię w chwilę po rozpoczęciu spektaklu, kiedy miał pewność, że na scenie od razu zastanie wspaniałego Danjūrō IX. Wuj zwierzał się też małemu Tanizakiemu, że bardzo nie lubił spektakli, w których aktor ten występował jednocześnie z Kikugorō $\mathrm{V}^{25}$.

W tym samym eseju Tanizaki opisuje też, jak duże wrażenie zrobiła na nim wycieczka szkolna do chramu sintoistycznego Mimeguri jinja w dzielnicy Mukōjima w Tokio, podczas której nauczyciel pokazał dzieciom kamień podarowany świątyni przez Danjūrō IX, z wyrytym fragmentem wiersza własnego autorstwa.

Tanizaki z nostalgią konkluduje, że był wtedy młody i nie znał się na teatrze, ale kiedy po latach oglądał sztuki kabuki, w których niegdyś podziwiał Danjūrō IX, zawsze porównywał jego grę z gestykulacją czy sposobem mówienia innych odtwórców tych samych ról. To pozwalało mu uświadomić sobie, jak głęboko doświadczenia dzieciństwa zapadły mu w pamięci.

Z eseju Rozmowy o sztuce można się dowiedzieć, że Tanizaki prywatnie znał wielu artystów kabuki i że czytał też ich wspomnienia. Właśnie pod wpływem tych lektur zaczął ich darzyć wielkim szacunkiem i uznaniem. Pisarz szczegółowo opisuje zwłaszcza wyczerpujące fizycznie treningi, mające na celu nieustanny rozwój. Wspomina na przykład, jak odwiedzając swego bliskiego znajomego, malarza Yasudę Yukihiko ${ }^{26}$, spotykał jego szwagra ${ }^{27}$ słynnego Nakamurę Kichiemona (1886-1954), a także jego ucznia, którym był starszy brat Yasudy - znany jako Nakamura Shichisaburō (1882-1966). Z upodobaniem rozprawiali wtedy o słynnych rolach Danjūrō IX i Ichikawy Danzō VIII (1882-1966) oraz o cechach ich aktorstwa.

W eseju Pory roku Tanizaki wyraża ponadto ubolewanie nad swoim pogarszającym się, uniemożliwiającym mu wychodzenie do teatru stanem zdrowia. Żałuje, że z powodu niedyspozycji nie mógł uczestniczyć w uroczystości nadania aktorowi pseudonimu artystycznego - Ichikawa Danjūrō XI ${ }^{28}(1909-1965)$. Dodaje, że chciałby ponownie zobaczyć sztukę Sukeroku (Galant Sukeroku, 1713) w takiej samej inscenizacji jak ta, którą w 1896 roku widział w Kabuki-za - wraz z matką i wujem. Żałuje, że z powodu niedyspozycji nie mógł uczestniczyć w uroczystości nadania aktorowi Ichikawie Ebizō IX, który zasłynął z roli tytułowej w sztuce Sukeroku, nowego pseudonimu artystycznego - Ichikawa Danjūrō XI (1909-1965).

Pisarz przyznaje się do rozdrażnienia, z jakim przyjął różne innowacje w kabuki, jak na przykład to, że aktorzy zaczęli zakładać rajstopy z trykotu zamiast, jak dawniej, smarować

${ }^{24}$ Idem, Shiki, [w:] TJZ, t. 19, s. 179.

25 Ibidem, s. 180

26 Yasuda Yukihiko (1884-1978) jeden z najważniejszych malarzy ery Taishō (1912-1926) i Shōwa (1926-1889), jeden z twórców nurtu japońskiego malarstwa zwanego nihonga. Zob. hasło "Yasuda Yukihiko", [w:] Köjien, s. 2680.

27 Yasuda był mężem starszej siostry Kichiemona.

${ }_{28}$ Aktor ten dopiero w kwietniu 1962 roku przyjął pseudonim Ichikawa Danjūrō XI. Wcześniej znany był jako Matsumoto Kōshirō, Ichikawa Shinnosuke czy Ichikawa Ebizō. Każdy pseudonim jest oznaką kolejnego awansu zawodowego. S. Kawatake, Gaisetsu nihon engekishi, s. 333. 
nogi białym podkładem oshiro ${ }^{29}$. Z niezadowoleniem odnotował też nowy zwyczaj usuwania ze sztuki sceny, w której tytułowy bohater kładzie drewniaki geta ${ }^{30}$ na głowę swego rywala ubiegającego się o serce pięknej kurtyzany Agemaki, starego Hige no Ikyū. Tanizaki obawia się, że nawet jeśli są to sprawy mało istotne, to dokonując tego rodzaju modyfikacji, kabuki może stopniowo zacząć tracić swój dawny urok ${ }^{31}$.

\section{Onoe Kikugorō VI}

Również Onoe Kikugorō VI (1885-1949) oraz Ichikawa Sadanji II (1880-1940) byli aktorami, których Tanizaki podziwiał, czemu dał wyraz w swoich esejach.

Refleksje na temat pierwszego z nich pisarz przedstawia szczegółowo w eseju Kronika gadulstwa. Pisze tam, że pogrzeb młodszego brata Onoe Kikugorō VI, w którym uczestniczył wraz z piastunką, zapamiętał jako jedno z najważniejszych przeżyć z okresu wczesnego dzieciństwa. Był wtedy pochmurny, deszczowy dzień. Kondukt pogrzebowy przechodził koło chramu Suitengū usytuowanego w pobliżu domu Tanizakiego. Mały Jun'ichirō miał okazję przyjrzeć się z bliska niepokrytym intensywnym makijażem twarzom wielu wybitnych aktorów kabuki. Nie mógł oderwać wzroku od pewnego chłopca. Niania wyjaśniła $\mathrm{mu}$, że był nim dziesięcioletni wówczas Kikugorō VI. Tanizakiego zafascynował wygląd tego nieletniego aktora, mającego na sobie kosztowne kimono, kurtę haori ${ }^{32}$, tradycyjne drewniaki geta, yamataka bōshi $i^{33}$ na głowie. Uwagę przyszłego pisarza przyciągała także biel twarzy. Tanizaki zastanawia się w eseju, czy to możliwe, aby mogła być ona pokryta grubą warstwą podkładu oshiroi. Pisze, że wszystko co wtedy widział, wydawało mu się zabawne i że pomyślał, iż chciałby mieć takie samo nakrycie głowy. Od tamtej pory za każdym razem, gdy Tanizaki słyszał nazwisko Onoe Kikugorō VI, odżywały w nim wspomnienia z tego pogrzebu i wywoływały nostalgię.

W Kronice gadulstwa pisarz wspomina ponadto ekscytację, z jaką po latach oglądał tego aktora na scenie kabuki. Jest przekonany, że w taką euforię można odczuwać tylko wtedy, gdy obcuje się z prawdziwym dziełem sztuki lub arcydziełem literackim. W pamięci pozostał mu także styl gry tego aktora, charakteryzujący się zmysłowością i szorstkością zarazem.

\section{Ichikawa Sadanji II}

Napisany w roku śmierci Ichikawy Sadanjiego II esej Wspominając ze smutkiem starego przyjaciela Ichikawę Sadanjiego jest swoistym epicedium poświęconym temu aktorowi. Tanizaki

\footnotetext{
${ }^{29}$ Oshiroi - śnieżnobiały podkład stosowany w makijażu aktorów kabuki (zarówno w wypadku ról żeńskich i męskich). Ma konsystencję fluidu. Na oshiroi nakłada się puder. Zob. E. Żeromska, Japoński teatr klasyczny, t. 2, s. 105-124.

${ }^{30}$ Geta - tradycyjne drewniaki japońskie.

31 J. Tanizaki, Shiki, [w:] TJZ, t. 19, s. 182.

${ }^{32}$ Haori - rodzaj kurty z długimi rękawami (lub bez rękawów) wkładanej na kimono.

33 Yamataka bōshi-japońska nazwa zaprojektowanego w 1850 r. w Wielkiej Brytanii melonika, który w Japonii został spopularyzowany w latach 70. XIX w.
} 
przyznaje, że Sadanji II był drugim - oprócz aktora shinpa ${ }^{34}$, Hanayagiego Shōtarō (18941965 ) - artystą teatralnym, z którym łączyły go przyjacielskie stosunki ${ }^{35}$. Wyznaje, że byli oni na tyle wyjątkowi, iż zaprzyjaźnił się z nimi, choć zwykle starał się zachowywać dystans w stosunku do aktorów i podtrzymywać jedynie kontakty zawodowe.

W tym samym eseju Tanizaki wspomina też, że kiedy chodził do szkoły podstawowej w tokijskiej dzielnicy Sakamoto, krążyła wśród dzieci pogłoska, że jednym z absolwentów tej szkoły jest dziecko wybitnego aktora z rodu Takashima. Dopiero po pewnym czasie pisarz dowiedział się, że to był starszy od niego o sześć lat Ichikawa Sadanji II, którego - ze względu na dużą różnicę wieku i brak możliwości zawarcia bliższej znajomości - nie mógł pamiętać.

W Czasie dzieciństwa Tanizaki wspomina dla odmiany, że rozpowiadano o tym, jak dzieci dokuczały przyszłemu wielkiemu aktorowi, wykrzykując za nim z pogardą: „Aktorskie dziecko! Aktorskie dziecko!"36, a on reagował na to płaczem i ucieczką do domu. Po latach Sadanji II, zapytany przez Tanizakigo, czy to prawda, stanowczo zaprzeczył.

Po raz pierwszy Tanizaki poznał Sadanjiego II w 1909 roku podczas prób do Na dnie Maksyma Gorkiego (1868-1936) w teatrze Meiji-za ${ }^{37}$ w Tokio. Aktor wcielił się w postać Satina, co postrzegano jako wielkie wydarzenie, gdyż zazwyczaj artyści kabuki nie decydowali się na tego rodzaju eksperymenty. Dowodziło to też wszechstronności zainteresowań i wielkiego talentu Sadanjiego. Tanizaki dokładnie nie miał pewności, kto mu go przedstawił: Watsuji Tetsurō $(1889-1960)^{38}$, kolega Tanizakiego z kółka literackiego czy może Osanai Kaoru (1881-1928) ${ }^{39}$ - redaktor „Shinshichō II” („Nowe Prądy II”), który we wrześniu 1910 roku opublikował na łamach tego czasopisma pierwszy utwór Tanizakiego (sztukę Narodziny) i utorował mu w ten sposób drogę do kariery.

Trwająca trzydzieści lat przyjaźń między Tanizakim i Sadanjim II nie narodziła się od razu. Początkowo pisarz odnosił się do aktora z nieufnością, ale obserwując go podczas prób, uświadomił sobie, że łączy ich taki sam młodzieńczy zapał i skłonność do marzycielstwa. Zawsze wolał bowiem zachowywać dystans wobec osób, które uważał za swoich mistrzów i od których czuł się zależny. W nawiązaniu bliższej relacji przeszkadzało mu to, że Sadanjiego łączyła zażyła znajomość z Osanai Kaoru oraz z Nagai Kafū (1879-1959), który wygłaszał wielce pochlebne opinie na temat talentu literackiego Tanizakiego (między innymi w listopadzie 1911 roku na łamach „Mita Bungaku” („Literatura Mita”) i dokładał wszelkich starań mających na celu ugruntowanie jego pozycji młodego pisarza.

\footnotetext{
${ }^{34}$ shinpa (nowa szkoła) - obok shingeki (nowy teatr), jeden z najważniejszych nurtów japońskiego teatru nowożytnego, powstały w latach 80. XIX w.

35 J. Tanizaki, Kyūyū Sadanji wo itamu, [w:] TJZ, t. 22, s. 341.

${ }^{36}$ Idem, Yōshōjidai, [w:] TJZ, t. 17, s. 82

${ }^{37}$ Meiji-za - teatr wybudowany w 1873 roku w Tokio; na jego scenie wystawiane są rodzime sztuki kabuki oraz shingeki.

${ }^{38}$ Watsuji Tetsurō - filozof japoński zajmujący się głównie logiką. Miał duży wkład w rozwój studiów nad historią Japonii oraz teorią kultury. Zob. hasło "Watsuji Tetsurō”, [w:] Kōjien, s. 2878.

${ }_{39}$ Osanai Kaoru - reżyser, organizator nowego teatru, dramaturg oraz pisarz. Wraz z Ichikawą Sadanjim II założył w 1910 r. zespół teatralny Jiyū Gekijō (Wolny Teatr). Brał też aktywny udział w działalności Tsukiji Shōgekijō, którego powstanie stanowiło drugi etap rozwoju shingeki (nowego teatru) w Japonii. Zob. hasło "Osanai Kaoru", [w:] ibidem, s. 368.
} 
Kiedy Tanizaki we wrześniu 1923 roku, po trzęsieniu ziemi w regionie Kantōo ${ }^{40}$, przeniósł się do Kioto, stopniowo oddalał się psychicznie od Sadanjiego II. Zmiana miejsca zamieszkania wpłynęła bowiem pośrednio na wzrost zainteresowania Tanizakiego powieścią, więc nie miało znaczenia, że aktor odwiedził go w Kioto wkrótce po przeprowadzce.

We Wspominajac ze smutkiem starego przyjaciela Ichikawe Sadanjiego Tanizaki daje upust swojej rozpaczy, którą odczuwał podczas pisania tego eseju. Wyznaje, że nie może sobie wybaczyć braku, iż nie odwzajemniał szczerej serdeczności Sadanjiego. Tłumaczy, że to najwidoczniej z powodu swojej samotniczej natury nie był w stanie zauważyć ani docenić zaufania i sympatii, jakimi obdarzył go aktor. Dopiero po jego śmierci zdał sobie z tego sprawę. Zawsze jednak widział w nim utalentowanego artystę, wspaniałego człowieka, aktywnego polityka oraz zaradnego przedsiębiorcę. Tanizaki przywołuje czasy, kiedy Sadanji II po śmierci swego poprzednika, Ichikawy Sadanjiego I (1842-1904), zdołał zmobilizować innych aktorów do podjęcia działania w celu niedopuszczenia do powstania kryzysu w kabuki. Pisze także o wielkim zaangażowaniu przyjaciela w tworzenie - wraz z Osanai Kaoru - Jiyū Gekijō w 1909 roku.

Pisarz z zaniepokojeniem myśli o przyszłości kabuki i daje wyraz przekonaniu, że trudno będzie znaleźć godnego następcę Sadanjiego II - wielkiego mentora i przywódcy młodych pokoleń aktorów. Ostatecznie wyznaje, że zmarły przyjaciel na długo pozostanie w jego pamięci.

W eseju zatytułowanym Wspomnienia związane z pamiątkami po nieobecnych, Tanizaki opisuje pamiątki otrzymane po śmierci swych przyjaciół i wyznaje, że od wdowy po Sadanjim II dostał skórzany pas $o b i^{41}$, tradycyjną kurtę haori ${ }^{42} \mathrm{z}$ herbem rodziny Takashima oraz haori z kaszmiru. Wszystkie te pamiątki starannie przechowuje w specjalnie przeznaczonej do tego skrzyni ${ }^{43}$.

\section{Dziadek Tanizaki i jego kabuki}

Ważnym dopełnieniem zawartej $\mathrm{w}$ esejach wiedzy na temat zainteresowań Tanizakiego Jun'ichirō teatrem kabuki są wspomnienia jego wnuczki, Watanabe Taori (ur. 1953), która w książce Sofu Tanizaki Jun'ichirō (Mój dziadek Tanizaki Jun'ichirō, 2003) dokładnie opisuje wizyty rodziny Tanizakich w teatrze $k a b u k i^{44}$. Wspomina między innymi, że pisarz doskonale znał swój ulubiony dramat Galant Sukeroku. Często nawet bawił się z nią w taki sposób, że wygłaszał z pamięci różne kwestie z tej sztuki, a ona musiała odgadywać, z jakiej sceny pochodzą dane fragmenty.

\footnotetext{
40 Trzęsienie ziemi w Tokio o sile 8,3 w skali Richtera (jap. Kantō daishinsai), które 1 września 1923 roku nawiedziło rejon Kantō, spowodowało śmierć około 140 tysięcy ludzi. Zniszczeniu uległo niemal całe Tokio i Yokohama. Tragedię spotęgował wielki pożar miast i jedenastometrowa fala tsunami.

${ }^{41} \mathrm{Obi}$ (pas) - nazwa wielu rodzajów pasów i szarf służących do przepasywania tradycyjnych japońskich kimon.

${ }^{42}$ Haori - rodzaj kurty z długimi rękawami (lub bez rękawów) wkładanej na kimono.

43 J. Tanizaki, Katami no shinajina ni matsuwaru omoide, [w:] TJZ, t. 23, s. 447.

44 T. Watanabe, Sofu Tanizaki Jun'ichirō (Mój dziadek Tanizaki Jun'ichirō), Tōkyō 2000, s. 82.
} 


\section{Kabuki w Dzienniku szalonego starca}

Potwierdzenie słów wnuczki znaleźć można w pierwszej scenie jednej z najsłynniejszych powieści Tanizakiego Füten rōjin nikki (Dziennik szalonego starca, 1961) ${ }^{45}$. Jest w niej zawarty opis, jak rodzina głównego bohatera Utsugi Tokusuke udaje się do teatru na Galanta Sukeroku. W tej samej scenie uwzględniona jest też ponadto krytyka tendencji do używania przez aktorów białych rajstop zamiast tradycyjnego pudrowania nóg. Tę zgodną z poglądem pisarza opinię wkłada on w usta Tokusuke - tytułowego starca będącego miłośnikiem tradycyjnego teatru japońskiego: „wszyscy aktorzy noszą dziś na nogach trykoty. Czasami trykoty się marszczą i to zupełnie psuje efekt. Zdecydowanie wolę nogi gołe, pokryte tylko pudrem" ${ }^{46}$.

Bohaterowie powieści, Tokusuke i jego żona, wspominają mistrzowskie - w ich przekonaniu - wykonania roli Sukeroku przez Ichimurę Uzaemona XIII (1844-1903) oraz Ichikawę Danjūrō IX. Starzec wyznaje też swą słabość do młodych aktorów kabuki i wyjawia, jak przeżył w przeszłości krótki młodzieńczy romans z jednym z odtwórców ról kobiecych onnagata ${ }^{47}$. Wychwala nie tylko zdolności tego aktora, lecz także jego doskonałą znajomość sztuki miłosnej.

\section{Ulubione sztuki pisarza}

We fragmencie Czasu dzieciństwa zatytułowanym „Danjūrō, Godaime Kikugorō, Nanase Danzō, sono ta no omoide” („Wspomnienia Danjūrō, Kikugorō V, Danzō VII i innych”) Tanizaki skupia się na repertuarze kabuki, z którym zapoznał się w młodości, chodząc w Tokio na przedstawienia do czterech dużych teatrów: Shintomi-za, Kabuki-za, Kotobuki-za, Masago-za, Meiji-za oraz do mniejszych teatrów w tokijskiej dzielnicy Asakusa. Autor ze szczegółami opisuje kunszt gry wymienionych w tytule eseju aktorów. Najwięcej uwagi poświęca jednak sztukom wystawianym w teatrze Nakamura-za, w których występował ulubiony aktor pisarza, Danjūrō IX: Nachi no taki chikai mongaku (Śluby mnicha Mongaku przy wodospadzie Nachi, 1889) Kawajiri Hōkina (XIX w.), Kokoro no nazo chūgi no eawase (Tajemnice serca, czyli galeria obrazów lojalności, 1889) Kawatake Mokuamiego, Yokoshimada ka no ko furisode (Włosy w nieładzie, kimono farbowane wzorem kanoko, 1868) Kawatake Mokuamiego. Pamięta też, jak matka uwielbiająca popis Danjūrō IX w czwartym akcie dramatu Takedy Izumo I (?-1747) Ashiya Dōman ōuchi kagami (Ashiya Dōman, czyli dworskie zwierciadło, 1734) ${ }^{48}$ zatytułowanym Kuzunoha ko wakare (Rozstanie Kuzunohy

45 J. Tanizaki, Dziennik szalonego starca, łłum. M. Melanowicz, [w:] Dziennik szalonego starca. Niektórzy wola pokrzywy; zob. także Füten rōjin nikki, [w:] TJZ, t. 19, s. 1-174.

46 Ibidem, s. 8.

47 Onnagata (inaczej: oyama) - wykonywana przez mężczyznę rola kobieca w teatrze kabuki. Ten typ roli wykształcił się w Japonii w XVII w. po wprowadzeniu (1629) przez siogunat edyktu zakazującego kobietom występowania na scenie. Od tamtej pory w przedstawieniach kabuki grają wyłącznie mężczyźni (tak jak w nō i kyōgen). Zob. S. Kawatake, Gaisetsu nihon engeki-shi (Zarys historii teatru japońskiego), Tōkyō 1976, s. 237; J. Rodowicz, hasła onnagata, tachiyaku [w:] J. Tubielewicz, op. cit., s. 244, 306.

48 Ashiya Dōman ōuchi kagami - pięcioaktowa sztuka historyczna (jidaimono), znana także pod tytułem Kuzunoha (dosł. „liść maranty”), została napisana dla teatru lalkowego przez Takedę Izumo w 1734 r. Jej premiera 
z dzieckiem) z rozrzewnieniem streszczała małemu Tanizakiemu fragment jednej ze scen, podczas której grający lisicę Kuzunohę Danjūrō IX, żegnając się z ukochanym dzieckiem, pisze do niego list. Historię tej lisicy Tanizaki znał też z dzieciństwa, gdyż była ona popularna wśród małych dzieci. Dodaje, że kiedy w wieku czterdziestu lat oglądał ten dramat w wersji przeznaczonej dla teatru lalkowego (bunraku) w Bunraku-za ${ }^{49}$ w Osace, lalkę przedstawiającą Kuzunohę animował legendarny Yoshida Bungorō IV (1869-1962).

\section{Esej Nocne rozmowy w „schronieniu po śniegu" jako źródło informacji o fascynacji sztuką Yoshitsune, czyli tysiąc wiśni}

W 1963 roku Tanizaki Jun’ichirō napisał składający się z czterech rozdziałów esej Nocne rozmowy w „schronieniu po śniegu”, którego bohaterką jest żona pisarza, Morita Matsuko oraz jej trzy siostry. Liczący prawie sto stron tekst jest zakończony oddzielnym, krótkim szkicem „Yoshitsune senbon-zakura” no omoide (Wspomnienia ze sztuki „Yoshitsune, czyli tysiąc wiśni”). Tytuł szkicu nawiązuje do popularnej sztuki kabuki zatytułowanej Yoshitsune

odbyła się w Takemoto-za w Osace w 1734 r. Sztuka oparta jest na motywach baśni o białej lisicy, która w dowód wdzięczności wobec Abe no Yasuny przybywa do niego zamieniona w jego zaginioną żonę o imieniu Kuzunoha. Lisica rodzi mu syna, ale kiedy prawda o jej lisim pochodzeniu wychodzi na jaw i w dodatku do domu Yasuny wraca jego prawdziwa żona, zmuszona jest uciekać do lasu Shinoda. Najbardziej znany jest czwarty akt tej sztuki pt. Kuzunoha kowakare (Rozstanie Kuzunohy z dzieckiem). Zob. R. Cavaye, P. Griffith, Senda A., A guide to the Japanese Stage. From Traditional to Cutting Edge, Tokyo 2004, s. 149-150.

49 Nazwa teatru Bunraku-za odnosi się do zespołu teatralnego stworzonego w Osace przez Uemurę Bunrakukena (1751-1810) w 1811 r., a także do miejsca, w którym odbywały się spektakle. Pierwsza siedziba zespołu znajdowała się na osiedlu Bakurō-machi w dzielnicy Nanba na terenie świątyni o tej samej nazwie, ale w 1842 r. na skutek reform bakufu, zwanych reformami Tenpō, zakazano spektakli na terenach świątynnych i teatr Bunraku-za musiał zawiesić działalność. Została ona wznowiona w 1856 r. ponownie na terenie świątyni Nanba. W 1872 r. siedzibę teatru przeniesiono do dzielnicy Matsushima - rozrywkowego centrum Osaki. Wtedy też oficjalnie zaczęto uzywać nazwy Bunraku-za. W 1884 r. teatr przeniesiono z Matsushimy do świątyni Goryōjinja w dzielnicy Centrum (Chūō-ku) w Osace.

Na początku XX wieku, z powodu poważnych problemów finansowych, zespół został wykupiony przez firmę producencką Shōchiku. W 1930 r. siedzibę teatru przeniono do nowego budynku w dzielnicy Yotsubashi w Osace. W 1945 r., ze względu na bombardowania amerykańskie, zespół zawiesił działalność. Wznowił ją w lutym 1946 r. W 1949 r. doszło do podziału grupy na dwa zespoły. Jeden z nich, zarządzany przez firmę Shōchiku, został nazwany Chinamikai (Towarzystwo Więzi), drugi, Sanwakai (Towarzystwo Trzech Harmonii) usamodzielnił się. W 1956 r. Chinamikai przeniesiono do dzielnicy Dōtonbori w Osace i zmieniono jego nazwę na Asahi-za.

W 1963 r. oba zespoły ponownie się połączyły, tworząc Zaidan Hōjin Bunraku Kyōkai (Stowarzyszenie Fundacji Bunraku). Teatr zaczął być dotowany już nie prywatnego przedsiębiorcę, jakim była firma Shōchiku, tylko przez państwo, urząd miasta Osaki, państwową stację telewizyjną NHK oraz różne organy władzy regionu Kansai. W maju 1984 r., znajdująca się w Osace w dzielnicy Nipponbashi, siedziba zespołu otrzymała obecną nazwę Kokuritsu Bunraku Gekijō (Narodowy Teatr Bunraku). Zob. S. Kawatake, op. cit., s. 217-226. 
senbon-zakura (Yoshitsune $\mathrm{e}^{50}$, czyli tysiąc wiśni) będącej adaptacją dramatu jōrurij ${ }^{51}$ napisanego przez Takedę Izumo II (1691-1756), Miyoshiego Shōraku (1695-1771) i Namikiegoo Senryū I (1695-1751). Prapremiera tego utworu odbyła się w 1747 roku w teatrze lalkowym Takemoto-za w Osace, a w 1748 roku - na scenie teatru kabuki Nakamura-za w Edo (obecne Tokio).

Tanizaki miał dziesięć lat, kiedy po raz pierwszy obejrzał tę sztukę (1896), a właściwie tylko jej czwarty akt ${ }^{52}$ zatytułowany Michiyuki hatsune no tabi (Michiyuki ${ }^{53}$ - podróż pierwszego dźwięku). Było to w Nowy Rok w teatrze Meiji-za, do którego został zabrany przez matkę i wuja Shōshichiego. Podczas tego samego przedstawienia wystawiono też trzecią scenę z trzeciego aktu Yoshitsune, czyli tysiąc wiśni. Miał wówczas okazję podziwiać wielkiego Onoe Kikugorō V. Szczególny zachwyt małego Tanizakiego wzbudziła scena (z czwartego aktu Yoshitsune, czyli tysiąc wiśni), kiedy grany przez tego aktora Satō Tadanobu, wierny sługa Yoshitsune, przeobraża się w lisa. Pisarz mówi o ciekawości, z jaką obserwował moment tej metamorfozy. Wspomina ponadto, że z podobnym zainteresowaniem i podziwem śledził też scenę z trzeciego aktu tej sztuki, w której są przedstawione perypetie miłosne Tairy Koremoriego i pięknej Osato.

\footnotetext{
50 Minamoto no Yoshitsune - generał japońskiego rodu Minamoto (Genji), dziewiąty syn sioguna Minamoto no Yoshitomo (1123-1160), młodszy brat sioguna Minamoto no Yoritomo - założyciela siogunatu Kamakura (1185-1333). Yoshitsune odznaczał się wybitnymi zdolnościami szermierczymi. W 1180 r. dołączył do brata, Yoritomo, i stanął u jego boku w wojnie Genpei (1180-11850). Po zakończeniu wojny Genpei brata Yoshitsune zaniepokoiły jego sukcesy na polu bitwy, dopatrywał się w nim rywala dążącego do przejęcia władzy w kraju. Dlatego też rzucił na niego podejrzenie o spiskowanie z cesarzem Goshirakawą (1127-1192). Yoshitsune skrył się u swego dawnego opiekuna Fujiwary Hidehiry (1122-1187), ale wydany przez jego syna wojskom Yoritomo musiał popełnić wraz z żoną Sato Gozen (1168-1189) i czteroletnią córką rytualne samobójstwo. Jest bardzo popularną postacią w japońskiej kulturze. W buddyjskiej świątyni Kurama na górze Hiei niedaleko Kioto odbywa się co roku 15 września festiwal na cześć Yoshitsune (Yoshitsune Matsuri). Zob. hasło „Minamoto no Yoshitsune", [w:] Kōjien, s. 2569.

51 Jōruri (właśc. ningyō jōruri) - jeden z trzech gatunków japońskiego teatru klasycznego (obok kabuki i nō), rodzaj teatru lalkowego przeznaczonego dla dorosłych. Rozwijał się równolegle z kabuki, dlatego oba gatunki mają wiele wspólnych cech. Elementami przedstawienia są narracja kantora (gidayū), akompaniament muzyczny na instrumencie (shamisen) oraz animacja marionetek (ayatsuri ningyō).

Japoński teatr lalkowy określa się powszechnie terminami: shibai jōruri, ningyō jōruri, jōruri, bunraku. Trzy ostatnie z wymienionych terminów często używa się wymiennie (nawet w Japonii), choć praktyka ta nie jest właściwa. Ta pojawiająca się powszechnie również w źródłach japońskich niekonsekwencja bardzo utrudnia stosowanie prawidłowego nazewnictwa.

Wiele osób nie zdaje sobie jednak sprawy z tego, że pozostałe odmiany japońskiego teatru lalek noszą inne nazwy. Na przykład w oddalonej od Osaki o około sto dwadzieścia kilometrów miejscowości Minamiawaji na wyspie Awaji (ojczyźnie japońskiego lalkarstwa) znajduje się zespół Awajiningyō-za (Teatr Lalkowy Awaji), którego pierwotny i rustykalny styl określa się terminem (awaji ningyō jōruri; inaczej: awaji ningyō shibai), styl, którego nie należy mylić z bunraku. O wyjątkowości stylu reprezentowanego przez artystów z Osaki najdobitniej świadczy natomiast fakt, że w 2003 r. tylko ich zespół został wpisany na listę światowego dziedzictwa kultury, a nie cały japoński teatr lalek.

Artystom z Awaji (tak jak lalkarzom z Osaki) zależy na podkreślaniu i pielęgnowaniu oryginalności własnego stylu. W tym celu na przykład na stronie internetowej swojego teatru podają bardzo dokładne zestawienie cech charakterystycznych awaji-ningyō jōruri oraz bunraku. Również Tanizaki Jun'ichirō w jedenastym rozdziale swojej powieści Niektórzy wolą pokrzywy bardzo szczegółowo przedstawia różnice między bunraku a awaji ningyō jōruri. Szerzej na ten temat: K. Niimi, Awaji ningyō shibai, Kōbe 1968; B. Kubiak Ho-Chi, Tragizm w japońskim teatrze lalkowym bunraku, Warszawa 2011; E. Żeromska, Japoński teatr klasyczny, t. 2, s. 233-385.

52 Dramat kabuki ma formę niejednolitą, przeplataną wstawkami epickimi i lirycznymi. Składa się często od kilku do kilkunastu aktów, z których każdy stanowi odrębną całość i może być wystawiany oddzielnie. Zob. hasło "kabuki”, [w:] J. Tubielewicz, op. cit., s. 131.

53 Michiyuki (pokonywanie drogi) - w sztukach kabuki i jōruri scena podróży; w jej trakcie wykonuje się tańce, których treścią są uczucia między zakochanymi w sobie kobietą i mężczyzną. Szerzej na ten temat zob. E. Żeromska, Japoński teatr klasyczny, t. 2, s. 196.
} 


\section{Wspomnienie Rozstania Kuzunohy $z$ dzieckiem}

W eseju Nocne rozmowy w „schronieniu po śniegu” Tanizaki przywołuje także obrazy z obejrzanego we wczesnym dzieciństwie wraz z matką czwartego aktu sztuki Ashiya Dōman ōuchi kagami (Ashiya Dōman, czyli dworskie zwierciadło, 1734) zatytułowanego Kuzunoha ko wakare (Rozstanie Kuzunohy z dzieckiem). Nie podaje jednak dokładnej daty ani nazwy teatru, do którego przyprowadziła go matka. Opisuje przede wszystkim, jak wielkie wrażenie wywarł na nim grający w spektaklu Ichikawa Danjūrō IX (1838-1903). Przyznaje jednak, że wprawdzie sceny pochodzące z Rozstania Kuzunohy z dzieckiem zainspirowały go do napisania opowiadania Yoshino kuzu (Maranta z Yoshino, 1931), lecz jego literacką wyobraźnię najbardziej poruszyła sztuka Yoshitsune, czyli tysiąc wiśni. Stwierdza: „Nigdy nie zdołałbym powołać na kartach tego opowiadania tak iluzorycznego świata, gdybym nie obejrzał właśnie Yoshitsune senbon-zakura z Kikugorō ${ }^{54 ”}$.

Rzeczywiście w opowiadaniu Maranta z Yoshino Tanizaki rozwinie motyw matki-lisicy i jej rozstania z dzieckiem zaczerpnięty z z czwartego aktu sztuki Yoshitsune, czyli tysiąc wiśni. Nawiąże też do wątku miłosnego z tego samego aktu.

\section{Uznanie dla Nakamury Fukusuke IV - odtwórcy roli Yoshitsune}

W eseju Wspomnienia ze sztuki „Yoshitsune, czyli tysiąc wiśni” Tanizaki dowodzi swojej przenikliwości i zmysłu krytycznego. Szczegółowo analizuje bowiem grę wszystkich wykonawców roli tytułowego Yoshitsune, których miał okazję widzieć na scenie. Zdaniem pisarza najwybitniejszym, najbardziej wiarygodnym odtwórcą tej roli był Nakamura Fukusuke IV (1866-1940 $)^{55}$. Tanizaki zwraca między innymi uwagę na fizyczne podobieństwo tego aktora i historycznego Minamoto no Yoshitsune $(1159-1189)^{56}$. Pisze, że „jako dziecko wyobrażałem sobie, że Yoshitsune musiał być młodzieńcem zaiste przepięknym, jak z obrazka" 57 .

Rozważania na temat Yoshitsune (bohatera sztuki) i odtwarzających tę postać aktorów kabuki Tanizaki kończy nieoczekiwanym stwierdzeniem, że w tym wypadku największe wrażenie wywarly na nim nie kreacje aktorskie, lecz portret tego wojownika namalowany przez przyjaciela pisarza, Yasudę Yukihiko (1884-1978).

Nie każdą kreację aktora Fukusuke IV Tanizaki oceniał pozytywnie. Rola nieszczęśliwie zakochanej Osato (z trzeciego aktu Yoshitsune, czyli tysiąc wiśni), w której aktor wystąpił podczas tego samego przedstawienia, nie zrobiła na pisarzu dużego wrażenia. Zawsze

\footnotetext{
54 J. Tanizaki, Setsugoan yawa, [w:] TJZ, t. 19, s. 454-455.

${ }_{55}$ Nakamura Fukusuke IV znany jest także jako Nakamura Utaemon V.

56 Zob. przyp. 50.

57 J. Tanizaki, Setsugoan yawa, [w:] TJZ, t. 19, s. 457.
} 
wrażliwy na doznania estetyczne Tanizaki z dezaprobatą komentuje na przykład fakt, że aktor jako Osato nie tylko nie miał przypudrowanych nóg, ale nawet nie był w rajstopach. Stwierdza, że z tego powodu artysta musiał odczuwać zimno, które z kolei sprawiło, iż jego zaczerwienione nogi tworzyły niepożądany kontrast z jaskrawą bielą wypudrowanej twarzy.

Mimo tego subtelnego dysonansu widok nagich stóp aktora w roli Osato zafascynował dziesięcioletniego Tanizakiego ${ }^{58}$. Możliwe, że już jako chłopiec był wrażliwy na piękno kobiecych stóp, które później będzie szczegółowo opisywać w swoich powieściach i opowiadaniach $^{59}$.

\section{Fascynacja lisem ze sztuki Ashiya Dōman, czyli dworskie zwierciadto}

W kolejnych fragmentach eseju Wspomnienia ze sztuki „Yoshitsune, czyli tysiąc wiśni” Tanizaki opowiada o tym, że motyw lisa ze sztuki Ashiya Dōman, czyli dworskie zwierciadto zainspirował pisarza i wywarł istotny wpływ na powstanie dramatu Byakko no yu $u^{60}$ (Kąpielisko białej lisicy, 1923). Tanizaki wyznaje, że również trzeci akt Yoshitsune, czyli tysiąc wiśni zainspirował go do napisania powieści Bushū kō hiwa (Tajemna historia pana Musashiego, 1931), a zwłaszcza scena mycia obciętych męskich głów przez piękne, skupione na tej czynności młode dziewczęta. Na wyobraźnię Tanizakiego oddziaływała fascynacja tytułowymi drzewami wiśni (sakura), kojarzonymi przez niego głównie z najpiękniejszym wspomnieniem $\mathrm{z}$ dzieciństwa i młodości, czyli z hanami ${ }^{61}$ spędzanym $\mathrm{z}$ rodziną $\mathrm{w}$ Tokio. Pora kwitnienia wiśni stała się najważniejszym dla pisarza okresem w roku, a kwitnąca wiśnia - jednym z ulubionych motywów w całej jego twórczości.

\section{Nagłe przerwanie edukacji teatralnej małego Tanizakiego i tęsknota za spektaklami oglądanymi z matką}

Z esejów Tanizakiego dowiadujemy się, że zamiłowanie do tradycyjnych japońskich widowisk zostało w nim rozbudzone w najmłodszych latach. Pisarz zapoznawał się kolejno z rytualnymi tańcami kagura i z komicznymi chaban, a następnie jako niespełna dziesięciolatek z teatrem kabuki, na którego deskach największe triumfy święciło trzech znakomitych

\footnotetext{
58 Ibidem.

59 Motyw nagiej kobiecej stopy pojawia się w takich utworach Tanizakiego jak Shisei (Tatuaż, 1909), Chijin no ai (Miłość szaleńca, 1924), Kagi (Klucz, 1956), Dziennik szalonego starca (1961).

60 J. Tanizaki, Byakko no yu, [w:] TJZ, t. 8, s. 487-516.

${ }^{61}$ Hanami (dosł. oglądanie kwiatów) - tradycyjny japoński zwyczaj podziwiania piękna kwiatów wiśni (sakura). Kwitnienie wiśni trwa od jednego do dwóch tygodni. W zależności od rejonu Japonii rozpoczyna się w marcu lub kwietniu.
} 
aktorów: Ichikawa Danjūrō IX, Onoe Kikugorō V, Ichikawa Sadanji I ${ }^{62}$. Z esejów dowiadujemy się też, że pisarz bardzo ubolewal, iż z powodu destabilizacji finansowej rodziny, która nastąpiła wtedy, gdy osiągnął dziesiąty rok życia, nie mógł chodzić do teatru tak często jak dawniej. Wprawdzie przez pewien czas ojciec Tanizakiego starał się rekompensować mu tę stratę, zabierając go na przedstawienia rakugo ${ }^{63}$, ale chłopcu to nie wystarczało nawet w najmniejszym stopniu. Sytuacja ulegała stopniowemu pogorszeniu, ponieważ wkrótce po bankructwie ojca również wujek Shōshichi, zmuszony zamknąć przynoszącą wielkie zyski drukarnię, bardzo zubożał.

Tanizaki dotkliwie odczuwał taki koniec pierwszego etapu swojej edukacji teatralnej, koniec zaakcentowany dodatkowo śmiercią Danjūrō IX (1903) i Kikugorō V (1903) oraz Sadanjiego I (1904), których często podziwiał na scenie. Z czasem zrozumie, że obcowanie z ich wielką sztuką sprzyjało jego uwrażliwieniu na piękno i stymulowało rozwój upodobań artystycznych. Na zawsze pozostanie w nim nostalgia.

Po latach w eseju Czas dzieciństwa autor opisze z rozrzewnieniem okres, kiedy jako siedemnastolatek zmuszony do łączenia nauki w liceum z pracą korepetytora, dojeżdżał do domu swoich uczniów koło teatru Kabuki-za i za każdym razem nakładały się w jego myślach wspomnienia matki, która w teatrze sadzała go na kolanach i tłumaczyła znaczenie treści oglądanych na scenie sztuk ${ }^{64}$.

Do tych tych wspomnień należy zaliczyć jeden z wątków opowiadania Oni no men ( $M a-$ ska diabła, 1916). Bohater tego utworu, Tsuboi Kōsaku, jest uczniem liceum i w dniu rozpoczęcia szkoły instynktownie postanawia pójść na przedstawienie do Kabuki-za. Kupuje wejściówkę, gdyż nie stać go na drogi bilet. Nie jest jednak zainteresowany tym, co dzieje się na scenie. Kontempluje jedynie przebywanie w teatrze - miejscu wywołującym intensywne wspomnienia wczesnego dzieciństwa, kojarzące mu się z twarzą matki trzymającej go na kolanach, kiedy był maleńkim chłopcem ${ }^{65}$.

Narrator powieści Tade kuu mushi (Niektórzy wola pokrzywy) ${ }^{66}$ opowiada o Kaname tokijczyku, który odwiedza teatr lalkowy Benten-za w Osace, dokąd został zaproszony przez teścia na sztukę Shinjū ten no Amijima (Samobójstwo dwojga kochanków w niebiańskiej Amijimie, 1720 $)^{67}$ Chikamatsu Monzaemona $(1653-1725)^{68}$. Bohater powieści, tak jak Tanizaki, wspomina czasy, gdy jako pięciolatek przyszedł z matką do teatru Kabuki-za: „Kiedy zdjął drewniane sandały i wszedł w skarpetkach tabi na gładkie i chłodne deski korytarza, przez ułamek sekundy obudziło się w nim wspomnienie matki z jakże odległych już czasów”.

\footnotetext{
62 Tę wielką aktorską trójcę nazwano w skrócie (od pierwszych sylab ich imion) Dan-Giku-Sa.

63 Rakugo (dosł. "spadające słowa”) - żartobliwy monolog wykonywany przez jednego gawędziarza (rakugoka; inaczej: hanashika) siedzącego na scenie i używającego jako rekwizytu jedynie papierowego wachlarza. Nie wstając z siedzenia przez cały czas trwania spektaklu, przedstawia długą i komiczną opowieść. Występują w niej zwykle dwie lub więcej postaci, których cechy indywidualne artysta różnicuje, odpowiednio zmieniając barwę i natężenie głosu.

64 J. Tanizaki, Yōshō jidai, [w:] TJZ, t. 17 , s. 184.

65 M. Yamaguchi, Nihon no sakka hyakunin, s. 52.

${ }^{66}$ J. Tanizaki, Niektórzy wolą pokrzywy, tłum. M. Melanowicz, [w:] Dziennik szalonego starca. Neiktórzy wolq pokrzywy.

${ }^{67}$ Shinjū ten no Amijima - trzyaktowa sztuka obyczajowa (sewamono) napisana dla teatru lalkowego jōruri. Jej premiera odbyła się w teatrze Takemoto-za w Osace, natomiast adaptacja kabuki w 1721 roku w teatrze Morita-za w Edo (Tokio).

${ }^{68}$ Chikamatsu Monzaemon - najwybitniejszy w dziejach japońskiego teatru klasycznego autor sztuk przeznaczonych dla teatru lalkowego oraz kabuki. Napisał ponad sto utworów. Szerzej na ten temat zob. B. Kubiak Ho-Chi, op. cit.; E. Żeromska, Japoński teatr klasyczny, t. 2, s. 32.
} 


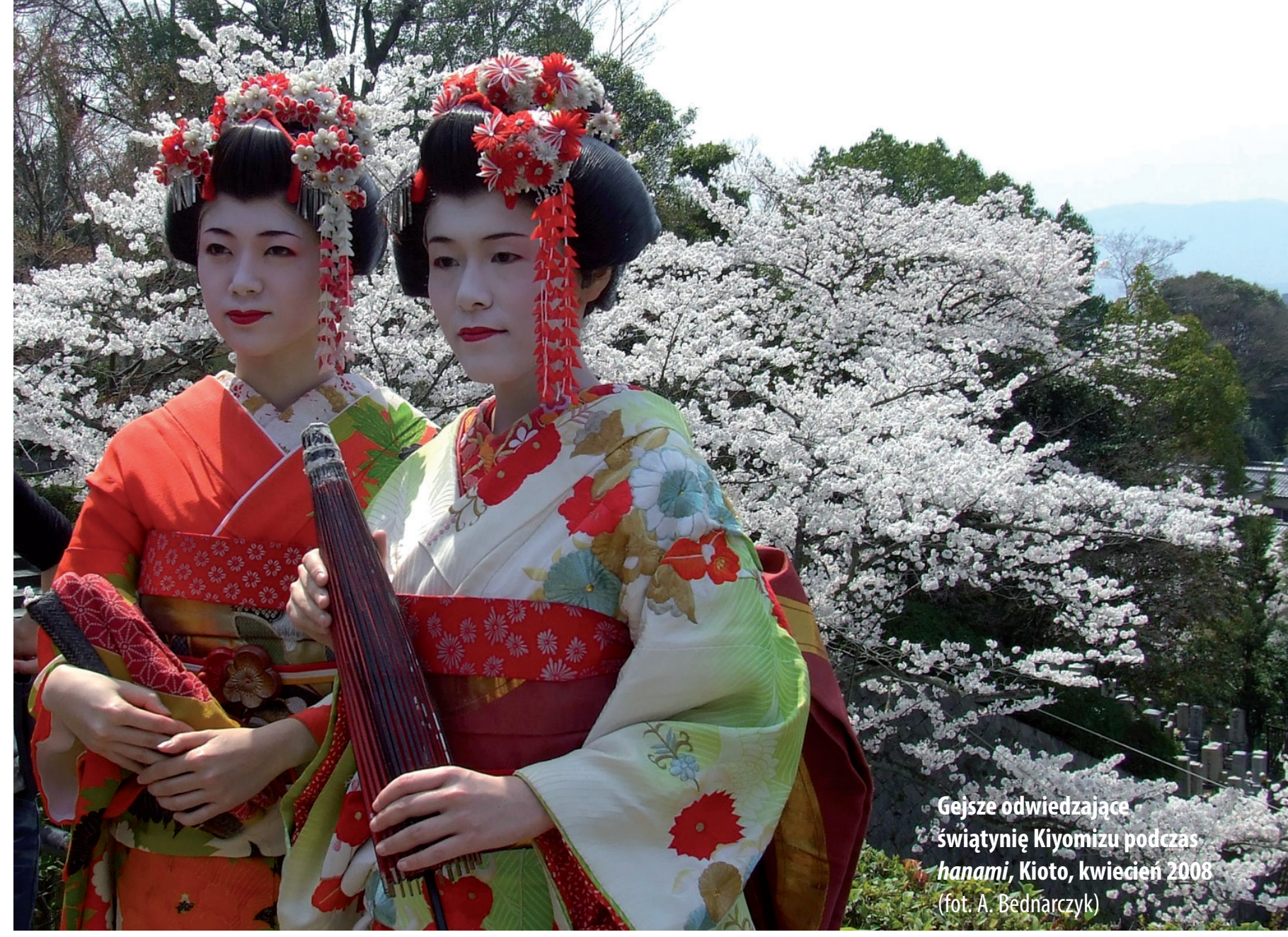

W Niektórzy wola pokrzywy opisana jest szczegółowo atmosfera panująca w teatrze w dawnych czasach, a nawet „dziwnie chłodne” powietrze. Bohater utworu „nawet teraz pamięta zimny powiew niby chłód mentolu przenikający przez rękawy i dól jego odświętnego kimona"69. Chłód ten wywoływał uczucie przyjemnego dreszczu, które porównuje do orzeźwiającego wiatru podczas oglądania kwiatów wiśni”70.

Tanizaki odczuwał wielką wdzięczność wobec wuja za wprowadzenie go w świat teatru kabuki i w Czasie dzieciństwa ponownie podkreśla, jak wielkie wrażenie zrobiły na nim sceny obejrzane w jego towarzystwie. Sądzi jednak, że wuj mógł zająć się jego edukacją teatralną z poczucia obowiązku wobec własnej siostry, której sytuacja finansowa nie pozwalała zapewnić dziecku tak luksusowych rozrywek. Wyraża też przekonanie, że wuj dostrzegał jego rosnące zainteresowanie i coraz lepsze rozumienie teatru.

W tym samym eseju Tanizaki zwierza się ponadto, że wspomnienia o tym, jak matka prowadzała go do teatru kabuki ożywały w nim pod wpływem należących do niej drzeworytów najsłynniejszych aktorów. Nie mógł odżałować, że cała kolekcja, którą odziedziczył po jej śmierci w maju 1917 roku, spłonęła ${ }^{71} \mathrm{w}$ pożarze tokijskiego domu, wywołanym trzęsieniem ziemi w 1923 roku.

69 J. Tanizaki, Dziennik szalonego starca, s. 170.

70 Ibidem.

71 J. Tanizaki, Yōshō jidai, [w:] TJZ, t. 17, s. 189. 


\section{Przeprowadzka do Kioto i tęsknota za kabuki}

Pierwszego września 1923 roku Tanizaki był świadkiem wielkiego trzęsienia ziemi w Tokio i okolicy. Stracił dom i majątek. Wraz z rodziną został zmuszony opuścić stolicę i znaleźć tymczasowe schronienie poza jej granicami. Udał się do Kioto, gdzie zatrzymał się u zaprzyjaźnionych aktorów, których poznał w okresie, kiedy działał na rzecz japońskiego filmu w wytwórni filmowej Taishō Katsuei ${ }^{72}$.

Kioto miało być tymczasowym schronieniem rodziny Tanizakich, do chwili całkowitego odbudowania stolicy. Okazało się jednak, że w tym przypadkowym miejscu zamieszkania pisarz odnalazł wiele inspiracji do stworzenia utworów uznanych później za najwybitniejsze w jego twórczości. Nie przestawał tęsknić za kabuki, które zapamiętał z okresu tokijskiego, ale w pobliskiej Osace odkrył i pokochał urokliwy teatr lalkowy (bunraku). Pi-

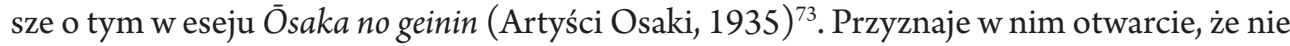
lubi stylu kabuki z regionu Kamigata (Kioto, Osaka) w przeciwieństwie do bunraku, którym od początku był zafascynowany ${ }^{74}$. W napisanym kilka lat wcześniej eseju Kronika gadulstwa narzeka, że odczuwa wielki niedosyt, ponieważ w Kansai brakuje dobrych spektakli kabu$k i^{75}$. Wyznaje: „Kiedy mieszkałem w Tokio, chodziłem do kabuki co najmniej raz w miesią$\mathrm{cu}$, ale już nie lubię teatru tak jak kiedyś. Odkąd tu przyjechałem, nadal marzę o oglądaniu kabuki, tylko nie bardzo mam z czego wybierać"76.

Dalej przyznaje, że wprawdzie do Kansai ${ }^{77}$ przyjeżdżają różni aktorzy z Tokio na występy gościnne, ale on najbardziej chciałby zobaczyć Onoe Kikugorō VI (1885-1949). Żartobliwie dodaje: „Kiedy jadę do Tokio i znajomi pytają mnie w restauracji, na co miałbym ochotę, odpowiadam: proszę mnie uraczyć dobrym spektaklem"78.

W Kronice gadulstwa Tanizaki informuje także, że powszechnie wiadomo, iż aktorzy tokijscy niechętnie odwiedzają Kamigatę, a jedynym miejscem, gdzie chcą występować jest teatr w Takarazuce ${ }^{79}$. Przyznaje, że wprawdzie może oglądać takich aktorów, jak Ichikawa Chūsha VII (1860-1936), Onoe Baikō VI (1860-1934), Nakamura Kichiemon I (1886-1954), ale bez możliwości podziwiania właśnie Kikugorō VI, ma wrażenie, jakby teatr w ogóle nie istniał ${ }^{80}$. Rozważania te Tanizaki zamyka krótką ripostą: „W Kamigata

\footnotetext{
72 Taishō Katsuei - wytwórnia filmowa powstała w Japonii w Yokohamie w kwietniu 1920 r. Zawiesiła swą działalność w 1922 roku, a rozwiązana została w maju 1925 r.

73 J. Tanizaki, Ōsaka no geinin, [w:] TJZ, t. 21, s. 263-270.

74 Ibidem, s. 63.

75 J. Tanizaki, Jōzetsuroku, [w:] TJZ, t. 20, s. 115.

76 Ibidem, s. 116.

77 Nazwa Kansai (inaczej: Keihanshin, Kinki) odnosi się do trzech głównych miast regionu, a mianowicie do Osaki, Kioto i Kobe. W swoich esejach Tanizaki posługuje się zwykle nazwą Kamigata na określenie Kansai. Przed restauracją Meiji (1868), ze względu na obecność w Kioto dworu cesarskiego, używano tego określenia w stosunku do Kioto i okolic. Na podstawie przedstawionych w niniejszej pracy esejów można wywnioskować, że Tanizaki pojmował nazwę Kamigata jako teren rozleglejszy, obejmujący nie tylko Kioto i jego okolice, ale również Osakę i Kobe.

78 J. Tanizaki, Jōzetsuroku, [w:] TJZ, t. 20, s. 116.

79 Takarazuka - nazwa siedziby zespołu teatralnego o tej samej nazwie powstałego w $1913 \mathrm{r}$. w miejscowości Takarazuka, niedaleko Osaki). Zob. hasło „Takarazuka”, [w:] J. Tubielewicz, s. 308.

${ }^{80}$ J. Tanizaki, Jōzetsuroku, [w:] TJZ, t. 20, s. 116.
} 
jest przepyszne jedzenie, takie jak: węgorz, tenpura ${ }^{81}$, soba $a^{82}$. Są tam moje ulubione restauracje, ale największy niedosyt wywołuje we mnie brak możliwości podziwiania Kikugorō VI"83. Z tego fragmentu wynika, że wykwintne jedzenie i dobra sztuka były dla pisarza nierozerwalne. Był wybrednym smakoszem i wybrednym teatromanem. Swoją pasją zaraził też wnuczkę, Watanabe Taori, która o tym pisze w swojej książce (Mój dziadek Tanizaki Jun'ichirō). Podkreśla, że mieszkając w Tokio, ogląda takie samo kabuki, jakie zapamiętał z dzieciństwa jej dziadek. Bez trudu można zauważyć, że w życiu Taori odegrał on zasadniczą rolę. Uwrażliwił ją na teatr tak samo jak wuj Shōshichi małego Tanizakiego.

Wpływ dziecięcej fascynacji teatrem kabuki na dojrzałą twórczość Tanizakiego Jun'ichirō najwcześniej dostrzegł mistrz Tanizakiego, wybitny pisarz Nagai Kafū. W artykule Tanizaki Jun'ichirō-shi no sakuhin (Utwory pana Tanizakiego Jun'ichirō), zamieszczonym w czasopiśmie „Mita Bungaku” w listopadzie 1911 roku, zwrócił on uwagę na cechy wyróżniające jego pisarstwo. Docenił doskonałość języka i stylu oraz jego mieszczański charakter. Wskazał też na niewątpliwie ważną rolę dramatu kabuki, wyjątkowo piękny, subtelny, a wyrazisty zarazem sposób opisywania scen przemocy wywołujących u odbiorcy doznania takie, jakie może zapewnić dzieło na najwyższym poziomie artystycznym ${ }^{84}$.

Niezbitym świadectwem uwielbienia Tanizakiego dla kabuki są napisane w latach 1910-1933 dwadzieścia cztery sztuki (i dodatkowo cztery utwory będące eksperymentami dramaturgicznymi), z których pierwsza, zatytułowana Tanjo $\overline{o s}^{85}$ (Narodziny, 1910) została opublikowana w czasopiśmie „Shinshichō II” i jest uważana za debiut literacki pisarza.

W utworach prozatorskich Tanizakiego natomiast bez trudu można odnaleźć motywy z zapamiętanych w dzieciństwie sztuk kabuki. Należą do nich między innymi kwiaty wiśni (sakura) i lis. Są to te same motywy, które pojawiają się też w utworach z repertuaru bunraku. Wprawdzie niewiele dzieł, w których można znaleźć ślady fascynacji pisarza tym klasycznym teatrem japońskim zostało przetłumaczonych na język polski, niemniej warto sięgnąć do zacytowanych tu Niektórzy wola pokrzywy czy Dziennika szalonego starca. Stanowią one bowiem najlepsze przykłady tego, jak młodzieńcza fascynacja Tanizakiego tradycyjnym japońskim teatrem mieszczańskim kabuki z czasem stała się wielką artystyczną inspiracją.

W przypisach, posłużono się skrótem TJZ oznaczającym: Tanizaki Jun'ichirō zenshū (Dzieła zebrane Tanizakiego Jun’ichirō), tomy 1-8 wydano w 1981 r., tomy 9-20 w 1982 r., tomy 21-30 w $1983 \mathrm{r}$.

\footnotetext{
81 Tenpura - tradycyjna potrawa japońska pochodząca z Portugalii. Przyrządza się ją z owoców morza i warzyw pokrojonych na niewielkie kawałki, które zanurza się w cieście naleśnikowym, a następnie krótko smaży na głębokim oleju.

82 Soba-cienki, długi makaron z mąki gryczanej; ważny składnik tradycyjnej kuchni japońskiej. Można go spożywać na zimno lub na ciepło.

83 J. Tanizaki, Jōzetsuroku, [w:] TJZ, t. 20, s. 117.

${ }^{84}$ M. Yamaguchi, Nihon no sakka hyakunin, s. 57.

85 J. Tanizaki, Tanjō, [w:] TJZ, t. 1, s. 1-16.
} 